\title{
On the issue of disposal of waste sorption material as an additive in new products' manufacturing
}

\author{
Darya Ignatkina $^{1^{*}}$, Victoria Telyatnikova ${ }^{2}$, Yaroslava Meshcheryakova ${ }^{3}$, and Gulnara \\ Gizzatova $^{4}$ \\ ${ }^{1}$ Volgograd State Technical University (VolgSTU), 400074, Volgograd, Russia \\ ${ }^{2}$ Volgograd State Social and Pedagogical University (VSSPU), 400005, Volgograd, Russia \\ ${ }^{3}$ Volgograd branch of the Russian University of Economics named after G.V. Plekhanov (Plekhanov \\ Russian University of Economics, Volgograd Branch), 400066, Volgograd, Russia \\ ${ }^{4}$ Volgograd State Agrarian University (VolgSAU). 400002, Volgograd, Russia
}

\begin{abstract}
Sorption is currently a promising method for purifying wastewater from organic and inorganic substances. The authors have developed a technology for obtaining a granular composite sorbent (GCS), on the basis of large-tonnage production waste - tobacco dust. However, as a result of sorption purification of highly concentrated wastewater from food industry enterprises, a significant amount of waste sorbent is formed, the regeneration of which is economically inexpedient. This article presents the laboratory studies' results, on the basis of which methods of GCS disposal were developed, exhausted its sorption resource for the new products' manufacturing in construction industry.
\end{abstract}

\section{Introduction}

In recent years, the problems associated with the water basin pollution have become aggravated. Discharge of untreated waste water (WW) in surface water bodies leads to a decrease in biodiversity and even the disappearance of life in ecosystems. One of the solutions to the environmental protection problem is the development and implementation of waste-free and low-waste technologies for cleaning industrial WW.

The most promising direction in the creation of effective environmentally friendly technologies for the processing of industrial WW is adsorptive cleaning [1,2]. One of the industries characterized by the formation of highly concentrated WW are the tobacco industry enterprises that are a part of food industry for which the method of sorption additional purification of substandard waters is the most economically justified and effective [3-5].

The authors of the article studied the adsorption processes of pollutants that make up WW enterprises of the tobacco industry in the Russian Federation using granular composite sorbent (GCS), the method of obtaining which was developed by the staff of the department

\footnotetext{
${ }^{*}$ Corresponding author: viv_vgasu@mail.ru
} 
"Water supply and sewerage" VolgSTU [6,7]. At the stage of adsorption purification of the designated production highly concentrated effluents, a significant amount of waste sorbent is formed, containing organic pollutants that are part of the WW - COD and BOD full, anionic surfactants (AS) and chlorine ions, in this regard, the question arises related to the GCS waste disposal $[8,9]$. The article presents the laboratory studies' results, on the basis of which the methods for the disposal of waste sorbent as a secondary raw material in the construction industry were proposed.

After using GCS sorption-filtering material for WW post-treatment enterprises of the tobacco industry in the Russian Federation from pollution, the concentration of which is many times higher than the permissible values even after electrochemical treatment (see Table 1), it is proposed not to regenerate it due to the economic inexpediency of this process due to the need to use a significant amount of water, but to recommend directions by the alternative methods GCS waste disposal as: a porous addition to the clay mass in the ceramic products manufacture [10-12] and one of the components of dry building mixtures for flooring [13-15].

Table 1 The composition of the WW contaminating components enterprises of the tobacco industry in the Russian Federation, the concentration of which exceeds the permissible values

\begin{tabular}{|c|c|c|c|}
\hline No. & Component name & Concentration & $\begin{array}{c}\text { Permissible } \\
\text { concentrations, in } \\
\text { accordance with the } \\
\text { Administration Decree } \\
\text { of Volgograd No. 3229 } \\
\text { from }\end{array}$ \\
\hline 1 & & & $\mathbf{2 4 . 1 0 . 2 0 1 1 .}$ \\
\hline 2 & BOD full & $178-180 \mathrm{mg} \cdot \mathrm{O}_{2} / \mathrm{dm}^{3}$ & 34.44 \\
\hline 3 & COD & $204-210 \mathrm{mg} \cdot \mathrm{O}_{2} / \mathrm{dm}^{3}$ & 51.66 \\
\hline 4 & AS & $0,9-1,2 \mathrm{mg} / \mathrm{dm}^{3}$ & 0.42 \\
\hline
\end{tabular}

\section{A porous addition to the clay mass in the manufacture of ceramic products}

The moisture content of the filtration sludge in the form of waste GCS, formed during the post-treatment of WW multicomponent, is about $75 \%$. In order to dispose the spent sorbent and eliminate the ingress of pollutants that make up the effluent of the tobacco factory (TF) into the environment, as well as to prevent the withdrawal of land from agricultural use, occupied by the storage of sediments resulting from wastewater treatment, in this work it is proposed to use waste GCS as a porous addition to the clay mass in the manufacture of unglazed tiles for cladding floors inside buildings.

According to the literary sources [10-15], the approximate composition of the mass that is used in the production of tiles for facing the floor surface inside the building is as follows: kaolin (5-10\%), clay (25-70\%), feldspar raw materials (13-25\%), quartz sand (10$15 \%)$, carbonate raw materials $(0-10 \%)$ and broken products $(5-10 \%)$. Previous studies to determine the GCS composition also confirm the presence of most of the above-listed component ingredients required for the production of unglazed floor tiles.

Based on GOST 6787-2001 "Ceramic tiles for floors. Technical conditions "tiles intended for flooring are produced by the method of semi-dry pressing, using the wet method for the raw materials' preparation. Therefore, large pieces of clay must first be crushed in roller mills or runners. Then the raw materials (clay, sand, fluxing agents, GCS) crushed together in ball mills in water until a homogeneous suspension (slick) with a 
particle size of less than $0.1 \mathrm{~mm}$ and a moisture content of $35-50 \%$ is obtained. Pressed workpieces are cleaned and dried mainly in vertical roller dryers. The drying temperature varies, depending on the technology used, from 120 to $350{ }^{\circ} \mathrm{C}$. The residual moisture content of the semi-finished product should not exceed $1 \%$. At the final stage, the tiles are fired for $0.5-1$ hours at temperatures of $950-1200^{\circ} \mathrm{C}$, after which they are sorted and packaged.

The proposed scheme for the unglazed tiles' production for cladding floors inside the building using waste GCS is shown in Fig. 1.

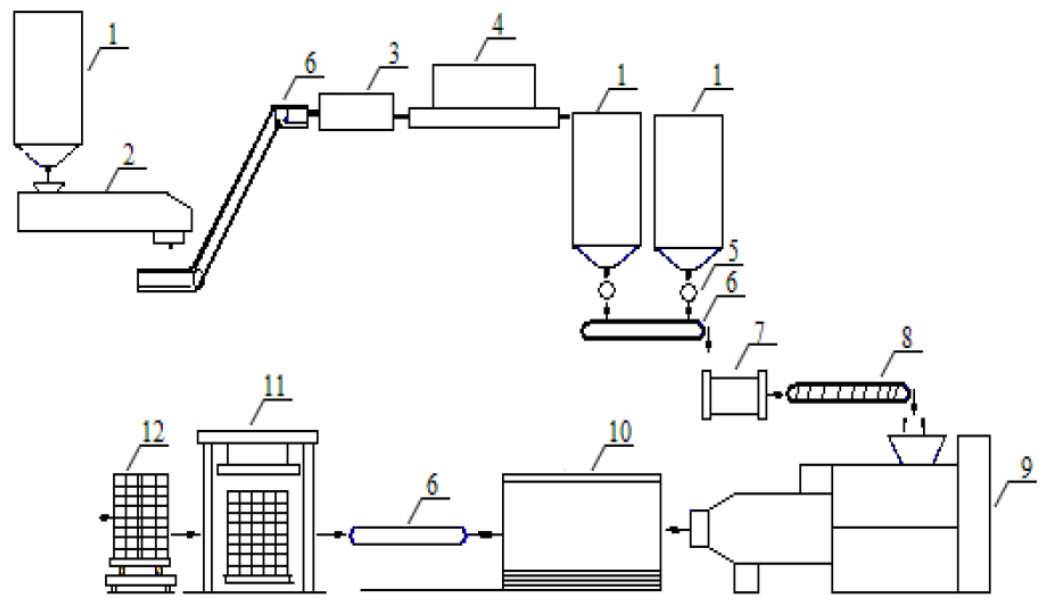

Fig. 1. Scheme of the production of unglazed tiles for cladding floors inside the building using GCS waste: 1 - bunker; 2 - siezing screen; 3 - edge mills; 4 - sieves; 5 - dispensers; 6 - belt conveyor; 7 mixer; 8 - screw conveyor; 9 - press; 10 - vertical roller dryer; 11 - kiln; 12 - ready-made prudence.

In laboratory conditions, firing of the molded samples - tiles of size $15 \times 15 \mathrm{~cm}$ and a thickness of $4 \mathrm{~mm}$ after drying in a drying oven at a temperature $120 \ldots 130{ }^{\circ} \mathrm{C}$ was carried out in a muffle furnace at a temperature $1020-1080{ }^{\circ} \mathrm{C}$ within 60 minutes.

Since the composition of the used $\mathrm{GCS} \mathrm{CaCO}_{3}$ and adsorbed multicomponent contaminants are included, then during the clay mass sintering, the reaction with the gaseous substances release is possible, which will promote pore formation in the body of the ceramic mass, which can lead to a decrease in the strength of the finished ceramic products and improve their heat and sound insulation properties. The results of determining the physical and mechanical parameters of the prototype using the GCS waste, obtained in laboratory conditions are presented in Table. 2.

Table 2. Physical and mechanical properties for unglazed tiles used for facing floors inside a building

\begin{tabular}{|c|c|c|c|}
\hline \multirow[b]{2}{*}{ No. } & \multirow[b]{2}{*}{ Indicator name } & \multicolumn{2}{|c|}{ Values for unglazed tiles } \\
\hline & & $\begin{array}{l}\text { according to } \\
\text { GOST } 6787- \\
2001 \\
\end{array}$ & $\begin{array}{c}\text { when adding GCS } \\
\text { waste }\end{array}$ \\
\hline 1 & Water absorption, $\%$, no more & 3.5 & 2.5 \\
\hline 2 & $\begin{array}{l}\text { Flexural strength, } \mathrm{mPa} \text {, not less, for } \\
\text { the tiles with a thickness of up to } \\
9.0 \mathrm{~mm} \text { inclusive }\end{array}$ & 28.0 & 32 \\
\hline
\end{tabular}




\begin{tabular}{|c|l|c|c|}
\hline $\mathbf{3}$ & $\begin{array}{l}\text { Wear resistance (on quartz sand), } \\
\mathrm{g} / \mathrm{cm}^{2}, \text { no more }\end{array}$ & 0.18 & 0.15 \\
\hline $\mathbf{4}$ & $\begin{array}{l}\text { Frost resistance, number of cycles, } \\
\text { not less }\end{array}$ & 25 & 50 \\
\hline
\end{tabular}

The test results presented in Table 2, indicate that when using GCS waste as an additive in the production of unglazed tiles, the established strength standards in accordance with GOST 6787-2001 are not reduced, which means that the resulting ceramic products can be used for finishing floor coverings inside buildings.

\section{Dry building mixtures for flooring}

Spent GCS, after post-treatment of waste liquid, is also proposed to be used as a waterreducing additive for the manufacture of dry building mixtures, which can be used as a leveling sub-base for flooring.

The water-reducing effect affects the solution workability, which in turn allows to reduce the water-cement ratio, as a result of which the mechanical strength increases without changing the consistency, as well as the tendency of stratification and water separation of the finished leveling mortar mixture decreases.

Technology for obtaining additives from GCS waste dry mix used in the construction of floors consists in drying the waste GCS in vivo, grinding it to a powdery state (particle size less than $0.1 \mathrm{~mm}$ ), heat treatment at a temperature $300-400{ }^{\circ} \mathrm{C}$ for 30 minutes to remove bound moisture. In the future, the resulting additive is mixed with the main components of the dry building mixture in the proportions given in table. 3 .

Table 3 The composition of dry building mixtures

\begin{tabular}{|c|c|c|c|c|c|}
\hline \multirow{2}{*}{ no. } & \multirow{2}{*}{ Functionality } & \multirow{2}{*}{ Brand } & \multicolumn{3}{|c|}{$\begin{array}{c}\text { Composition by weight with a cement grade } \\
\text { of at least } 400\end{array}$} \\
\hline & & & Cement & Sand & $\begin{array}{l}\text { GCS waste-based } \\
\text { additive }\end{array}$ \\
\hline \multirow{2}{*}{1} & \multirow{2}{*}{ For floor screeds } & 150 & 1 & 3 & 0.3 \\
\hline & & 200 & 1 & 2.8 & 0.35 \\
\hline 2 & $\begin{array}{l}\text { For leveling the } \\
\text { coating }\end{array}$ & 300 & 1 & 2.4 & 0.4 \\
\hline
\end{tabular}

Thus, based on the results obtained, presented in Table 3, it can be argued that a dry mixture mixed with water with an additive from GCS waste with a constant water-cement ratio, transforms into a super-plastic solution, without reducing the final mechanical strength and gives a possibility to obtain a structure with an improved surface quality, devoid of pores and cells.

Laboratory tests carried out in accordance with 8.2 GOST 30459 - 2008 "Additives for concrete and mortar", as well as a comparative analysis of technical specifications TS 5745001-00000-2016 "Dry building mixes for flooring", with the results obtained in the study of the samples made with the GCS waste addition for compliance with technical requirements. The results are presented in Table 4. 
Table 4. Test results for leveling mortars

\begin{tabular}{|c|c|c|c|}
\hline No. & The name of indicators & $\begin{array}{c}\text { The value of } \\
\text { indicators for brands } \\
\text { of dry mixtures } \\
\text { floor leveling } \\
\text { according to TS }\end{array}$ & $\begin{array}{c}\text { Mix for the floor } \\
\text { construction } \\
\text { with an additive } \\
\text { based on GCS } \\
\text { waste }\end{array}$ \\
\hline 1 & 2 & 3 & 4 \\
\hline 1 & Dry mix moisture, no more, $\%$ & 0.5 & 0.5 \\
\hline 2 & $\begin{array}{l}\text { Granulometric } \\
\text { composition, sieve residue No. } \\
1.25 \text {, no more, } \% \text {; No. } 0.63 \text {, no } \\
\text { more, } \%\end{array}$ & $\begin{array}{c}5 \\
10\end{array}$ & $\begin{array}{l}0 \\
5\end{array}$ \\
\hline 3 & $\begin{array}{l}\text { Mobility, immersion cone depth, } \\
\text { cm }\end{array}$ & $4-5$ & $4-5$ \\
\hline 4 & $\begin{array}{l}\text { Water-holding capacity of the } \\
\text { mixture, not less, } \%\end{array}$ & 95 & 98.3 \\
\hline 5 & $\begin{array}{l}\text { Solution spreading diameter, } \mathrm{cm} \\
\text { - not less } \\
\text { - no more }\end{array}$ & $\begin{array}{c}9 \\
12\end{array}$ & $\begin{array}{l}12 \\
15\end{array}$ \\
\hline 6 & $\begin{array}{l}\text { Solution viability, min, not less - } \\
20\end{array}$ & 20 & 30 \\
\hline 7 & $\begin{array}{l}\text { Setting time start, not earlier, min } \\
\text { end, not later, min }\end{array}$ & $\begin{array}{c}40 \\
180 \\
\end{array}$ & $\begin{array}{c}40 \\
180 \\
\end{array}$ \\
\hline $\begin{array}{l}8 \\
9\end{array}$ & $\begin{array}{l}\text { Ultimate strength, at the age of } \\
28 \text { days, not less, MPa: - under } \\
\text { compression }\end{array}$ & 20 & 18 \\
\hline 10 & $\begin{array}{l}\text { Adhesion strength to the base at } \\
\text { the age of } 28 \text { days, not less, MPa }\end{array}$ & 0.3 & 0.5 \\
\hline 11 & $\begin{array}{l}\text { Frost resistance, not less than } \\
\text { cycles }\end{array}$ & 35 & 35 \\
\hline 12 & Shrinkage, no more, $\mathrm{mm} / \mathrm{m}$ & 1.0 & 1.5 \\
\hline
\end{tabular}

The results of the research showed that the proposed dry building mixtures with the addition of GCS waste meet the requirements TS 5745-001-00000-2016 "Dry building mixes for flooring" and can be used for flooring as a water-reducing additive.

\section{Conclusion}

Thus, the presented results confirm the possibility of using the GCS waste as a secondary raw material in the manufacture of products in construction industry:

1) it is possible to use GCS waste as an additive in the production of unglazed tiles for interior flooring;

2) spent GCS can be used as a water-reducing additive for the production of dry mortars, which can be used as a leveling base for flooring

\section{References}

1. A.M. Koganovsky [et.al.], Adsorption technology of wastewater treatment (Technique, Kiev, 1981) 
2. V.Ya. Akhmadeev, N.V. Savina, Physicochemical methods and basic theoretical principles of adsorptive purification of waste water from organic compounds (Central Research Institute "Electronics", Moscow, 1975)

3. Adsorption: progress in fundamental and application research, selected reports at the 4th pacific basic conference on absorption science and technology, World scientific Publishing company incorporated, (2007)

4. D.M. Jisti, R. A. Conway, J. Water Poll. Control fed 46, 947 (1974)

5. M.M. Zuckerman, A.H. Molof, Water Poll. Control fed. 42, 43 (1970)

6. D.O. Ignatkina [et.al.], Patent 2644880 Russian Federation, B01J 20/24 (2006.01) A method of obtaining a sorbent for purifying waste water from multicomponent pollution [Text], VolgSTU. - No 2017108520 ; issue 14.03.2017 ; publ. 14.02.2018, No $5 .-10 \mathrm{p}$.

7. D.O. Ignatkina [et al.], Bulletin of the Volgograd State University of Architecture and Civil Engineering. Series: Construction and architecture, 49 (68), 110-121 (2017)

8. D.O. Ignatkina, E.V. Moskvicheva, E.P. Doskina, A.V. Moskvicheva, A.A. Voytyuk, Water supply and sanitary engineering (WST) 3, 36-44 (2018)

9. E.P. Doskina, E.V. Moskvicheva, A.A. Voytyuk, D.O. Ignatkina, Bulletin of the Volgograd State University of Architecture and Civil Engineering. Series: Construction and architecture 49 (60), 134-143 (2017)

10. A.A. Galenko, M.V. Pleshko, Building materials 4, $60-65$ (2014)

11. A. P. Zubekhin, N. D. Yatsenko, Building materials 1(2), 88-92 (2014)

12. A.G. Kaptyushina, V.S. Gryzlov, Stroitelnye materialy 12, 25-27 (2015)

13. A. Benlalla, Applied Clay Science 118, 171-177 (2015)

14. D.D. Kotelnikov, A.I. Konyukhov, Clay minerals of sedimentary rocks (Nedra, Moscow, 1986)

15. A.Yu. Stolboushkin, Building materials 2, 10-13 (2011) 